\title{
Acute pancreatitis in acute viral hepatitis
}

\author{
Pankaj Jain, Sandeep Nijhawan, Ramesh Roop Rai, Subhash Nepalia, Amit Mathur
}

Pankaj Jain, Sandeep Nijhawan, Ramesh Roop Rai, Subhash Nepalia, Amit Mathur, Department of Gastroenterology, SMS Medical College, Jaipur, Rajasthan, India

Correspondence to: Sandeep Nijhawan, Professor, Department of Gastroenterology, SMS Medical College, Jaipur, Rajasthan, India.dr_nijhawan@yahoo.com

Telephone: +91-141-2722335 Fax: +91-141-2560994

Received: May 10, $2007 \quad$ Revised: September 6, 2007

\begin{abstract}
AIM: To elucidate the frequency and characteristics of pancreatic involvement in the course of acute (nonfulminant) viral hepatitis.
\end{abstract}

METHODS: We prospectively assessed the pancreatic involvement in patients with acute viral hepatitis who presented with severe abdominal pain.

RESULTS: We studied 124 patients with acute viral hepatitis, of whom 24 presented with severe abdominal pain. Seven patients $(5.65 \%)$ were diagnosed to have acute pancreatitis. All were young males. Five patients had pancreatitis in the first week and two in the fourth week after the onset of jaundice. The pancreatitis was mild and all had uneventful recovery from both pancreatitis and hepatitis on conservative treatment. The etiology of pancreatitis was hepatitis $E$ virus in 4, hepatitis A virus in 2, and hepatitis B virus in 1 patient. One patient had biliary sludge along with HEV infection. The abdominal pain of remaining seventeen patients was attributed to stretching of Glisson's capsule.

CONCLUSION: Acute pancreatitis occurs in $5.65 \%$ of patients with acute viral hepatitis, it is mild and recovers with conservative management.

(C) 2007 WJG. All rights reserved.

Key words: Acute hepatitis; Pancreatitis; Viruses; Pain; Abdomen

Jain P, Nijhawan S, Rai RR, Nepalia S, Mathur A. Acute pancreatitis in acute viral hepatitis. World J Gastroenterol 2007; 13(43): 5741-5744

http://www.wjgnet.com/1007-9327/13/5741.asp

\section{INTRODUCTION}

Although hepatitis viruses have a strong tropism for hepatocytes, viral antigens have also been detected in other tissues such as the pancreas and gallbladder ${ }^{[1,2]}$. Several viral infections have been implicated as an aetiological factor of acute pancreatitis. The viruses most frequently responsible are mumps virus, Coxsackie B virus, Epstein-Barr virus and measles virus ${ }^{[3-6]}$.

Acute pancreatitis is not uncommon in fulminant hepatic failure (FHF) and has been confirmed based on histology or serology ${ }^{[7-9]}$. Acute pancreatitis has been reported very rarely in acute (nonfulminant) viral hepatitis. It has been reported with hepatitis A (HAV), hepatitis B (HBV) and non-A-non-B (blood-borne) and hepatitis $\mathrm{E}$ virus (HEV) infection ${ }^{[10-20]}$.

The aim of this study was to determine the frequency and characteristics of pancreatic involvement in the course of acute viral hepatitis.

\section{MATERIALS AND METHODS}

\section{Materials}

Patients seen at the gastroenterology clinic and ward of SMS hospital, Jaipur between January 2004 and December 2006 were included in this prospective study. Acute viral hepatitis was defined as patients with prodromal symptoms, deep jaundice, markedly raised transaminases, presence of markers of hepatitis $B$ (positive for $\mathrm{HBsAg}$, IgM anti-HBc, $\mathrm{HBeAg}$, but negative for anti-HBe), hepatitis A (IgM anti-HAV), hepatitis C (anti-HCV), hepatitis E (IgM-anti-HEV) viruses in serum and ultrasound abdomen showing thick walled gallbladder and hypoechoic liver. Patients with other causes of acute hepatitis, chronic liver disease, history of alcohol intake and fulminant hepatic failure were excluded from the study.

The diagnosis of acute pancreatitis was based on pancreatic type abdominal pain, raised amylase and lipase levels to three times the upper limit of normal and ultrasound (US) or contrast enhanced computed tomography (CECT) of abdomen suggestive of acute pancreatitis.

\section{Methods}

The acute viral hepatitis group underwent hemogram, serum bilirubin, serum aspartate aminotransferase (AST), serum alanine aminotransferase (ALT), serum alkaline phosphatase, prothrombin time, $\mathrm{HBs} \mathrm{Ag}, \mathrm{IgM}$ anti-HBc, $\mathrm{HBe} \mathrm{Ag}$, anti-HBe, IgM anti-HAV, anti-HCV, IgM antiHEV and ultrasound abdomen. Serum amylase and lipase, US of the abdomen and/or CECT were done in patients who had severe abdominal pain. Informed consent was obtained from each patient. 
Table 1 Clinical and laboratory characteristics of 124 patients of acute viral hepatitis

\begin{tabular}{|c|c|c|c|}
\hline & Acute viral hepatitis A $(n=16)$ & Acute viral hepatitis B $(n=54)$ & Acute viral hepatitis E $(n=54)$ \\
\hline Male: Female & 13:3 & $42: 12$ & 39:15 \\
\hline Age $(y r)^{1}$ & $18.3(8-35)$ & $36(20-74)$ & $33.6(17-62)$ \\
\hline \multicolumn{4}{|l|}{ Clinical features } \\
\hline Jaundice & $15(93.8)$ & $54(100)$ & $54(100)$ \\
\hline Prodromal symptoms & $16(100)$ & $54(100)$ & $54(100)$ \\
\hline Pain abdomen & $4(25)$ & $8(14.8)$ & $12(22.2)$ \\
\hline Pruritis & $4(25)$ & $9(16.6)$ & $19(35.2)$ \\
\hline Hepatomegaly (\%) & $6(37.5)$ & $16(29.6)$ & $21(38.9)$ \\
\hline Splenomegaly (\%) & $2(12.5)$ & $6(11.1)$ & $5(9.2)$ \\
\hline Hemoglobin $(\mathrm{gm} / \mathrm{dL})^{1}$ & $12.3(9.6-14.5)$ & $12.4(9-15.1)$ & $12.6(9-14.7)$ \\
\hline Platelets $\left(\times 10^{5} / \mathrm{mm}^{3}\right)^{1}$ & $2.5(1.8-3.2)$ & $1.8(1.2-2.5)$ & $1.6(1-3.4)$ \\
\hline Total leucocyte count $\left(\times 1000 / \mathrm{mm}^{3}\right)^{1}$ & $7.9(6.4-10.5)$ & $8.4(5-10.1)$ & $7.2(6-10.6)$ \\
\hline Bilirubin $(\mathrm{mg} / \mathrm{dL})^{1}$ & $9.4(0.67-35.8)$ & $12.4(3-36.5)$ & $10.7(3.3-26.3)$ \\
\hline $\operatorname{AST}(\mathrm{IU} / \mathrm{L})^{1}$ & $1969(60-7715)$ & $824(223-3600)$ & $1621.1(240-3684)$ \\
\hline $\operatorname{ALT}(\mathrm{IU} / \mathrm{L})^{1}$ & $2134.3(56-5165)$ & $1024(489-4900)$ & $1830.6(240-5549)$ \\
\hline Serum alkaline phosphatase $(\mathrm{IU} / \mathrm{L})^{1}$ & $521.9(196-1426)$ & $424.5(110-860)$ & $324(114-647)$ \\
\hline Protein/Albumin $(\mathrm{gm} / \mathrm{dL})^{1}$ & $7.2(6.5-7.8) / 4.0(3.5-4.6)$ & $7(6-8) / 3.9(3.4-4.8)$ & $6.5(5.5-8) / 3.8(3.4-4.6)$ \\
\hline Prothrombin time prolongation ${ }^{1}$ & $4(2-14)$ & $5.5(1-11)$ & $6(3-18)$ \\
\hline \multicolumn{4}{|l|}{ Ultrasonography of the abdomen } \\
\hline Thickened gallbladder & $14(87.5)$ & $38(70.4)$ & $44(81.5)$ \\
\hline Hypoechoic liver & $8(50)$ & $24(44.6)$ & $26(48.1)$ \\
\hline Gallbladder sludge & $2(12.5)$ & $2(3.7)$ & $3(5.5)$ \\
\hline Ascites & $1(6.25)$ & $3(5.5)$ & $26(48.1)$ \\
\hline Bulky pancreas & $2(12.5)$ & $1(1.8)$ & $4(7.4)$ \\
\hline
\end{tabular}

${ }^{1}$ Mean (range).

\section{RESULTS}

We had 124 patients with acute viral hepatitis over the three-year period, consisting of 94 males and 30 females, with a mean age of 32.7 years (range $8-65$ ). The viral serology assays showed $\mathrm{HBsAg}$ and IgM-anti-HBc in 54 patients, IgM anti-HEV in 54 and IgM anti-HAV in 16 (Table 1). Twenty-four patients (19.4\%) presented with history of severe abdominal pain, and 7 of these $(29.2 \%)$ had evidence of acute pancreatitis. So, $5.65 \%$ of patients with acute viral hepatitis presented with acute pancreatitis. In the remaining 17 patients, the amylase and lipase were less than three times the upper limit of the normal. They did not have evidence of acute (calculous or acalculous) cholecystitis. We attributed the abdominal pain to stretching of the Glisson's capsule.

The clinical, laboratory and radiological profile of the patients with acute pancreatitis is given in Tables 2 and 3. The mean age was 23.9 (range 11-32) years, all were males. Abdominal pain occurred 2-30 (mean 12) days after the onset of jaundice. The duration of abdominal pain ranged from 24 to $120 \mathrm{~h}$. None of the patients had a past history of jaundice, abdominal pain, alcoholism, trauma, hyperparathyroidism or drug intake. All patients had jaundice at presentation, mild hepatomegaly and epigastric tenderness. Three patients also had features of ileus.

On investigation, mean bilirubin was $16.4 \mathrm{mg} / \mathrm{dL}$ (range 5.8-32.4 mg/dL), mean AST 519 (range 182-1313) $\mathrm{U} / \mathrm{L}$ and mean ALT 1371.1 (range 702-2438) U/L. Amylase and lipase ranged from 275-596 (mean 364.6) $\mathrm{U} / \mathrm{L}$ and 520-7258 (mean 2495.4) U/L respectively. Serum lipid profile and calcium levels were normal in all patients. IgM anti-HEV, IgM anti-HAV, IgM anti-HBc were positive in 4,2 and 1 patient respectively. US could detect pancreatitis in three patients, minimal ascites and biliary sludge in one patient. An abdominal CECT showed edematous and enlarged pancreas in all patients. There was no evidence of necrosis. The patient with sludge showed complete resolution in 2 wk. None of the other patients had evidence of biliary sludge during follow-up. The pancreatitis and hepatitis responded to conservative treatment in all patients. All patients are asymptomatic after a mean follow-up of 12 (range 8-24) mo.

\section{DISCUSSION}

Most cases of acute pancreatitis due to hepatitis viruses had been reported in association with acute liver failure (ALF). In the autopsy series of Ham and Fitzpatrick, 14 of the $42(33 \%)$ patients with ALF had acute pancreatitis ${ }^{[8]}$, the majority being of viral etiology. Similar findings had been reported by Parbhoo et al ${ }^{[9]}$ in 21 out of 59 patients (36\%) with ALF who had acute pancreatitis. Autopsy findings of pancreatitis in seven of $16(44 \%)$ patients with fulminant viral hepatitis, versus two of $33(6 \%)$ patients with fulminant hepatic failure secondary to halothane, support the role of viral infection rather than liver failure per se in causing pancreatitis ${ }^{[21]}$.

There are only a few case reports of symptomatic pancreatitis occurring in the setting of acute viral hepatitis ${ }^{[10]}$. Most of the patients reported had presented with symptomatic pancreatitis in the early phase of the hepatitic illness ${ }^{[11-20]}$ whereas Mishra et a ${ }^{[10]}$ reported 6 patients at wk 2 or 3 after the onset of jaundice. Our series had five patients presenting in the first week and two in the fourth week after the onset of jaundice. One patient had biliary sludge and presented in the first week of jaundice. Ultrasound was done weekly in all the patients until clinical and biochemical resolution. Gallbladder wall thickness 
Table 2 Clinical Profile of viral hepatitis patients with acute pancreatitis

\begin{tabular}{|c|c|c|c|c|c|c|c|}
\hline & Case 1 & Case 2 & Case 3 & Case 4 & Case 5 & Case 6 & Case 7 \\
\hline Age (yr) & 11 & 30 & 32 & 21 & 30 & 20 & 23 \\
\hline Gender & M & M & M & M & $\mathrm{M}$ & $\mathrm{M}$ & $\mathrm{M}$ \\
\hline Pain interval after onset of jaundice (d) & 30 & 28 & 3 & 2 & 5 & 6 & 5 \\
\hline Pain duration (h) & 96 & 72 & 120 & 96 & 24 & 48 & 72 \\
\hline Hepatomegaly (cm; subcostal) & 5 & 2 & 2 & 3 & 3 & 2 & 3 \\
\hline Etiology & Hepatitis A & Hepatitis B & Hepatitis E & Hepatitis E & Hepatitis E & Hepatitis A & Hepatitis E \\
\hline $\begin{array}{l}\text { Recovery from } \\
\text { pancreatitis (d) }\end{array}$ & 8 & 6 & 12 & 6 & 3 & 6 & 4 \\
\hline Recovery from hepatitis (wk) & 8 & 6 & 12 & 8 & 8 & 12 & 10 \\
\hline
\end{tabular}

Table 3 Laboratory profile of viral hepatitis patients with acute pancreatitis

\begin{tabular}{|c|c|c|c|c|c|c|c|}
\hline Parameter & Case 1 & Case 2 & Case 3 & Case 4 & Case 5 & Case 6 & Case 7 \\
\hline Bilirubin (mg/dL) & 32.4 & 21.3 & 14.6 & 11.8 & 5.8 & 13.1 & 15.8 \\
\hline AST (IU / L) & 682 & 1210 & 1313 & 182 & 388 & 1223 & 765 \\
\hline $\operatorname{ALT}(\mathrm{IU} / \mathrm{L})$ & 895 & 702 & 2238 & 702 & 412 & 2438 & 814 \\
\hline Alkaline phosphates (IU/L) & 560 & 300 & 607 & 420 & 531 & 503 & 231 \\
\hline Albumin (mg/dL) & 3.8 & 4 & 3.5 & 3.8 & 3.5 & 3.9 & 3.5 \\
\hline Prothrombin time prolongation (s) & 14 & 11 & 12 & 9 & 11 & 10 & 18 \\
\hline Amylase (IU/L) & 475 & 460 & 275 & 278 & 462 & 319 & 596 \\
\hline Lipase (IU/L) & 7258 & 520 & 3297 & 990 & 760 & 2926 & 2060 \\
\hline Corrected Serum calcium (mg/dL) & 9.2 & 9.1 & 9 & 8.9 & 9.2 & 9.3 & 8.1 \\
\hline Serum triglyceride $(\mathrm{mg} / \mathrm{dL})$ & 140 & 168 & 131 & 165 & 141 & 160 & 154 \\
\hline Ultrasonography (Gallbladder) & Normal & Normal & Normal & Normal & Normal & Normal & Biliary sludge \\
\hline
\end{tabular}

(more than $3 \mathrm{~mm}$ ) was found in $96.8 \%$ of patients, which is in agreement with a previous study by Sharma et al ${ }^{[22]}$. None of the two patients who presented later had any evidence of biliary sludge on US.

The etiology of pancreatitis was considered to be due to a hepatitis virus in all patients, as there was no evidence of gallstones, sludge, alcohol, drugs, trauma or metabolic causes. The remaining patient had biliary sludge on US. The disappearance of biliary sludge at 2 wk occurred a week later than previously reported ${ }^{[23]}$. None of the 7 patients with biliary sludge had an episode of acute pancreatitis and gallbladder contraction was similar in the hepatitis and control group in the Portincasa $e t$ a ${ }^{[23]}$ group. So, the patient might had HEV-associated pancreatitis and had biliary sludge during the acute phase of the viral illness which resolved on follow-up ultrasound abdomen. Basaranoglu et a ${ }^{[24]}$ reported a case of gallbladder sludge and acute pancreatitis induced by acute hepatitis $A$.

Acute pancreatitis in nonfulminant acute viral hepatitis covers the full range of clinical severity. Subclinical pancreatic involvement in viral hepatitis may occur more commonly than is appreciated ${ }^{[25]}$. The pancreatitis was mild as reported previously ${ }^{[10,13-20]}$. One of our patients had minimal ascites which resolved in 2 wk. There were no local or systemic complications and all had uneventful recovery from both pancreatitis and hepatitis. No relation was found between the level of amylase and severity of pancreatitis.

The frequency of acute pancreatitis in acute viral hepatitis in the present series is $5.65 \%$, which is $2 \%$ higher than reported by Joshi et $a^{[2]}$ in their autopsy series of 108 cases. Joske $e a^{[27]}$ noted 8 cases of acute viral hepatitis out of 90 patients of acute pancreatitis.

The mechanism of pancreatitis in patients with acute viral hepatitis (nonfulminant) is unknown, and it may be multifactorial. One proposed pathogenesis of pancreatitis associated with hepatitis is the development of edema of the ampulla of Vater with obstruction to the outflow of pancreatic fluid ${ }^{[28]}$. There is no direct evidence for the routes by which hepatitis viruses reach the pancreas; however, the proposed routes are most likely blood or bile ${ }^{[14]}$.

A more plausible mechanism for viral associated acute pancreatitis is direct inflammation and destruction of pancreatic acinar cell by the virus. This latter theory is supported by the autopsy finding of hepatitis B virus antigens within the cytoplasm of pancreatic acinar cells of patients with hepatitis B surface antigenemia ${ }^{[1,2]}$. It is possible that the severity of pancreatitis is related to the magnitude of exposure of pancreatic acinar cells to the hepatitis virus ${ }^{[2]}$.

The hepatitis viruses might injure the pancreatic acinar cell membrane, resulting in the leakage of intracellular enzymes, and/or precipitate a network of intracellular events culminating in cell death by a mechanism analogous to hepatocyte necrosis ${ }^{[29]}$. Another mechanism can be the release and circulation of lysosomal enzymes from the inflamed liver with the activation of trypsinogen to trypsin.

When acute pancreatitis is associated with fulminant hepatitis, the virus may cause tissue damage directly, but there are several other factors which can play an important role in the development of pancreatitis (clinical or silent) and these include acute liver failure, hypotension, infections and drug induced damage ${ }^{[13]}$. Intrapancreatic 
hemorrhage due to hypoprothrombinemia or disseminated intravascular coagulation may result in pancreatic damage and subsequent pancreatitis ${ }^{[8]}$.

In conclusion, acute pancreatitis is not uncommon. In a patient with acute viral hepatitis and acute or disproportionate abdominal pain, acute pancreatitis should be kept as a possibility. Conservative treatment leads to recovery in all the patients.

\section{COMMENTS}

\section{Background}

The association of hepatitis viruses with acute pancreatitis in the setting of acute (nonfulminant) viral hepatitis is rare. The frequency and characteristics of pancreatic involvement in the course of acute viral hepatitis needs to be elucidated.

\section{Research frontiers}

Studies with larger number of patients of acute viral hepatitis with pain abdomen are necessary to determine the frequency and characteristics of pancreatitis as there are only case reports and one case series of six patients.

\section{Innovations and breakthrough}

Recent reports describe acute pancreatitis as a cause of acute or dispropionate abdominal pain complicating acute viral hepatitis.

\section{Applications}

Patients of acute viral hepatitis with severe pain abdomen should undergo serum amylase, lipase and ultrasonography or contrast-enhanced computed tomography of the abdomen to prove acute pancreatitis as a cause of abdominal pain. The prognosis of patients with acute pancreatitis in the setting of acute viral hepatitis is good and patients recover on conservative treatment.

\section{Terminology}

Acute viral hepatitis is defined as presence of prodromal symptoms, deep jaundice, markedly raised transaminases, presence of markers of hepatitis $B$ (positive for $\mathrm{HBsAg}, \mathrm{IgM}$ anti-HBc, $\mathrm{HBeAg}$, but negative for anti-HBe), hepatitis A (IgM anti-HAV), hepatitis C (anti-HCV), hepatitis E (IgM-anti-HEV) viruses in serum and ultrasound abdomen showing thick walled gallbladder and hypoechoic liver . Patients with other causes of acute hepatitis, chronic liver disease, history of alcohol intake and fulminant hepatic failure were excluded from the study. The diagnosis of acute pancreatitis was based on pancreatic type abdominal pain, raised amylase and lipase levels to three times upper limit of the normal and ultrasound (US) or contrast enhanced computed tomography (CECT) of the abdomen suggestive of acute pancreatitis.

\section{Peer review}

This article describes the clinical findings of acute pancreatitis in acute viral hepatitis. The main content of the manuscript is good.

\section{REFERENCES}

1 Hoefs JC, Renner IG, Askhcavai M, Redeker AG. Hepatitis B surface antigen in pancreatic and biliary secretions. Gastroenterology 1980; 79: 191-194

2 Shimoda T, Shikata T, Karasawa T, Tsukagoshi S, Yoshimura M, Sakurai I. Light microscopic localization of hepatitis B virus antigens in the human pancreas. Possibility of multiplication of hepatitis B virus in the human pancreas. Gastroenterology 1981; 81: 998-1005

3 Parenti DM, Steinberg W, Kang P. Infectious causes of acute pancreatitis. Pancreas 1996; 13: 356-371

4 Wislocki LC. Acute pancreatitis in infectious mononucleosis. N Engl J Med 1966; 275: 322-323

5 Ursing B. Acute pancreatitis in coxsackie B infection. Br Med J 1973; 3: 524-525
6 Naficy K, Nategh R, Ghadimi H. Mumps pancreatitis without parotitis. Br Med J 1973; 1: 529

7 Ede RJ, Moore KP, Marshall WJ, Williams R. Frequency of pancreatitis in fulminant hepatic failure using isoenzyme markers. Gut 1988; 29: 778-781

8 Ham JM, Fitzpatrick P. Acute pancreatitis in patients with acute hepatic failure. Am J Dig Dis 1973; 18: 1079-1083

9 Parbhoo SP, Welch J, Sherlock S. Acute pancreatitis in patients with fulminant hepatic failure. Gut 1973; 14: 428

10 Mishra A, Saigal S, Gupta R, Sarin SK. Acute pancreatitis associated with viral hepatitis: a report of six cases with review of literature. Am J Gastroenterol 1999; 94: 2292-2295

11 Maity SG, Ray G. Severe acute pancreatitis in acute hepatitis E. Indian J Gastroenterol 2002; 21: 37-38

12 Batra Y, Chakravarty S, Bhatt G. Severe acute pancreatitis associated with acute hepatitis A: a case report. Trop Gastroenterol 2003; 24: 27-28

13 Lopez Morante A, Rodriguez de Lope C, San Miguel G, Pons Romero F. Acute pancreatitis in hepatitis A infection. Postgrad Med J 1986; 62: 407-408

14 Davis TV, Keeffe EB. Acute pancreatitis associated with acute hepatitis A. Am J Gastroenterol 1992; 87: 1648-1650

15 Amarapurkar DN, Begani MM, Mirchandani K. Acute pancreatitis in hepatitis A infection. Trop Gastroenterol 1996; 17: 30-31

16 Eugene C, Cadranel JF, Bergue A, Anciaux ML. Acute pancreatitis associated with non-A-non-B hepatitis. Report of a case. J Clin Gastroenterol 1990; 12: 195-197

17 de Oliveira LC, Rezende PB, Ferreira AL, de Freitas AA, de Carvalho AM, Guedes CA, Costa WO. Concurrent acute hepatitis and pancreatitis associated with hepatitis B virus: case report. Pancreas 1998; 16: 559-561

18 Jaroszewicz J, Flisiak R, Kalinowska A, Wierzbicka I, Prokopowicz D. Acute hepatitis E complicated by acute pancreatitis: a case report and literature review. Pancreas 2005 30: $382-384$

19 Makharia GK, Garg PK, Tandon RK. Acute pancreatitis associated with acute hepatitis E infection. Trop Gastroenterol 2003; 24: 200-201

20 Khanna S, Vij JC. Severe acute pancreatitis due to hepatitis A virus infection in a patient of acute viral hepatitis. Trop Gastroenterol 2003; 24: 25-26

21 Geokas MC, Olsen H, Swanson V, Rinderknecht H. The association of viral hepatitis and acute pancreatitis. Calif Med 1972; 117: 1-7

22 Sharma MP, Dasarathy S. Gallbladder abnormalities in acute viral hepatitis: a prospective ultrasound evaluation. J Clin Gastroenterol 1991; 13: 697-700

23 Portincasa P, Moschetta A, Di Ciaula A, Palmieri VO, Milella M, Pastore G, Palasciano G. Changes of gallbladder and gastric dynamics in patients with acute hepatitis A. Eur J Clin Invest 2001; 31: 617-622

24 Basaranoglu M, Balci NC, Klör HU. Gallbladder sludge and acute pancreatitis induced by acute hepatitis A. Pancreatology 2006; 6: 141-144

25 Lechi A, Montesi G, Solbiati M, Dattoli R, Rizzotti P, Zanchetta M, Perobelli L, Burlina A. Serum pancreatic enzyme alterations in acute viral hepatitis. Hepatogastroenterology 1983, 30: $233-235$

26 Joshi RA, Probstein JG, Blumenthal HT. A survey of experiences with three hundred clinical and one hundred and eight autopsy cases of acute pancreatitis. Am Surg 1957; 23: 34-42

27 Joske RA. Aetiological factors in the pancreatitis syndrome. $\mathrm{Br}$ Med J 1955; 2: 1477-1481

28 Tsui CY, Burch GE, Harb JM. Pancreatitis in mice infected with coxsackievirus B1. Arch Pathol 1972; 93: 379-389

29 Lever AM. Mechanisms of virally induced liver damage. J Hepatol 1987; 4: 399-403

30 Lopez Morante A, Rodriguez de Lope C, San Miguel G, Pons Romero F. Acute pancreatitis in hepatitis A infection. Postgrad Med J 1986; 62: 407-408 